\title{
Renewable energy resources in Serbia and Russia
}

\begin{abstract}
Energy Policy of the Republic of Serbia and Russia is entirely based on the principles of sustainable development and the Kyoto Protocol. This paper reviews in details the characteristics of energy policy in Serbia and Russia and provides examples of certain kinds of energy. Serbia and Russia are rich in renewable energy resources. The explorations of mineral and thermal mineral water sources carried out in Serbia have shown high quality mineral waters that can be used for medical purposes. Mineral and thermal mineral sources in health resorts, in Serbia, represent natural resources with large possibilities for the development of tourism, health tourism, agriculture and other economic activities. Special attention should be directed to the needed multidisciplinary research projects for the purpose of the relevant criteria necessary for usage of every thermal mineral water. Intensive exploitation of the renewable resources must become one of the important aims of economic development in Serbia.
\end{abstract}

Keywords: renewable energy sources, biomass, biofuel, wind energy, tidal energy, geothermal energy, Republic of Serbia, Russian Federation

\section{INTRODUCTION}

All the countries in the world face a difficult problem, and that is how to reduce the use of fossil fuels and the emissive amounts of harmful gases which cause the greenhouse effect, global warming, climate changes, and the occurrence of acid rain. This further leads to the ozone depletion, various natural disasters, and in addition, it causes problems to keep the level of technological and economic development [5].

The only way to deal with these issues is to reduce the use of fossil fuels and to develop technology of renewable energy sources. By replacement of fossil fuels with renewable sources, we can achieve a significant impact on successful solutions of global environmental problems.

Today, the use of renewable resources is becoming more important, especially for the reasons of environmental preservation and the usage of resources already available on own territory.

The potentiality of the use of renewable energy sources is high in the Republic of Serbia, and it is estimated to be over 4,5 million tonnes of oil equivalent a year.

The Government of Serbia in February 2013 adopted the draft law on energy efficiency, which covers all aspects that affect the cost of the municipalities in the area. The National Action Plan for Renewable Energy received a positive opinion of the energy community in accordance with the

Author's address: ${ }^{1}$ ALFA University, Belgrade, Serbia, ${ }^{2}$ V.I. Vernadsky Institute of Geochemistry and Analytical Chemistry of the Russian Academy of Sciences, Moscow, Russia, ${ }^{3}$ Singidunum University (FEFA), Belgrade

Received for Publication: 10 .01. 2014.

Accepted for Publication: 16. 04. 2014. development plan of the Republic of Serbia to the 2020. The Republic of Serbia is committed to increasing the share of renewable energy in total energy consumption to 27 percent by 2020 .

Serbia, in the next six years, is expected to receive two billion US dollars of investment in projects implementation of renewable energy sources in order to introduce new green energy capacity (up to $1092 \mathrm{MW}$ ). Among them is the wind farm (500 MW), hydropower plant (200 MW), biomass processing plant (200 MW), and plants that use energy from other renewable sources (192 MW), which will allow the stabilization of the energy system. This will also contribute to the creation of jobs in the sector of green industries and it will prevent environmental problems.

For the development of a sustainable energy system in Serbia, it is necessary to use the experience of other Balkan countries, as well as advanced technologies developed in Russia and the European Union.

The aim of this paper is to analyze positive trends in the use of renewable energy sources in the Russian Federation along with the progress of Serbia in the introduction of new renewable energy capacity.

\section{USAGE OF BIOMASS RESOURCES}

Biomass is used in some regions of the country to provide a total of $1 \%$, or 9 Twh/year, of Russia's total energy. However, due to Russia's enormous forest and peat reserves, [nb 1] it has a total biomass technical potential of $431 \mathrm{Twh} / \mathrm{year}$, of which $285 \mathrm{Twh} / \mathrm{year}$ is economically feasible [16]. Most of this potential is to be found in northwestern Russia, which has a developed pulp and paper industry that can provide wood-based waste to use as biomass energy [19, 20, 22].

The use of peat for energy production was significant during the former Soviet Union, with a 
peak reaching in 1965 and decreasing from that point. In 1929 , over $40 \%$ of the Soviet Union's electric power came from peat, which dropped to only $1 \%$ by 1980 . Currently, Russia accounts for $17 \%$ of the world's peat production. Twenty percent of the peat that the country produces, i.e.,1.5 million tons, is used for energy purposes. The two biggest peat power stations in the world are Shatura Power Station in Moscow Oblast and Kirov Power Station in Kirov Oblast.

The possibilities for use of biomass are numerous. Biofuels are fuels from renewable resources like plants - and animal sources. Biofuels have distinctive chemical and physical properties that are close to fuels from fossil fuels. They can be used to exchanging petrodiesel in existing engines.

The biofuels are much cleaner for the environment, and they have potential to solve other problems of environmental protection (like waste management), or if the source of the biofuels is algae that are grown in water that has to be cleared. These sources generate the fuel whose price will depend more on microeconomic than on macroeconomic factors. In this way, economies of many countries will be protected from external economic crises.

In addition to the remains and waste, there is a large number of plant species that are possible to grow: from the fast growing trees with the annual yield of 17 tons per hectare, and to the green algae with a yield of 50 tons per hectare.

Biofuels, which are most widely used, comprise biodiesel and bioalcohols with ethanol accounting for more than $90 \%$ of global production of biofuels.

The Republic of Serbia accepted the obligation to adopt and implement a plan that concerns the application of the Directive 2001/77/EC about the promotion of the production of electrical energy from renewable energy resources. Serbia has done this with the ratification of the Energy Community of Southeast Europe countries.

The Directive 2001/77/EC clearly defines renewable energy resources. The Directive provides for the setting of national targets for consumption of electricity generated from renewable energy resources. The Directive also provides the measures necessary to achieve the targets. Programs are reviewed quinquennially and the member states are obligated to report to the European Commission on their achievement. The Directive also incurporates an obligation of every country to analyze and improve the existing legal frameworks and administrative procedures. These issues are indispensable for the building and exploitation of plants that generate electricity from renewable energy resources.

In 2008, the European Parliament formally approved a set of legislation on climate change. This set of legislation should aim to provide a decrease in emissions of greenhouse gases by $20 \%$, enhancing energy efficiency by $20 \%$ and share of renewable energy from $20 \%$ in total energy consumption in the EU - till 2020, in comparison with 1990.

The Directive 2009/28/EC about renewable energy sets binding national targets which member states of the Union need to achieve through the promotional activities of renewable energy in the sectors of electrical energy, heating and cooling and the transport sector. This should ensure that, by 2020 , the renewable energy amounts to at least $20 \%$ of total energy consumption in the European Union. Member countries are under an obligation to adopt and inform the European Commission about the National Action Plans for the realization of the proposed goals. The member countries should also ensure that procedures for approval, certificates and permits are made simple in order to eliminate barriers to developing a market for renewable energy.

Unfortunately, the production of energy from biomass, which can be considered as a very promising source of renewable energy in Serbia, is still limited to their production of pellets and briquettes, in forestry and agroindustry. Serbia has significant potential for the production of raw materials for processing into biodiesel, which is estimated at about $10 \%$ of the total area of arable land. This area can provide enough raw materials for an annual production of 210 to 250 tons of biodiesel, which could replace about $13-16 \%$ mineral diesel in Serbia [22].

The most important raw material for the production of biodiesel is oilseed rape with $82.8 \%$ of the world production. In addition, there is significant production of biodiesel from sunflower oil with $12.5 \%$ of the world production (the remaining $4 \%$ cover other cereal oils, for example, corn).

Serbia has developed its own technology, engineering and technical procedures for transesterification of oils and fats obtained by extrusion of grain crops. It has also developed final by-products, such as meal, glycerol, salt and soap into quality products for animal feed and raw materials for chemical industry.

Plants for the production of biodiesel by batch method, with a capacity up to $1000 \mathrm{t}$, are in preparation for the construction in Sombor, Melenci, Knjaževac, Backa Topola, and some other places.

However, in Serbia, biodiesel was not mass produced not even in 2013. Its mass production is not competitive in relation to the production of mineral diesel.

Russia's biofuel production is of recent existence, but it has recently been developing with rapidity in recent years. Russia is one of the largest grain producers in the world with a well-developed ethyl alcohol production and has an increasing 
rapeseed (often used to create biodiesel) production rates. The Russian government made an official declaration in 2008 that it would engage itself actively in developing the biofuel industry by erecting 30 new biofuel plants and providing various tax incentives. There are some estimates that Russia has the capability to export 40 million tons of biofuel annually.

The antioxidant additives are generally added to the biodiesel, as well as additives that increase the temperature and the turbidity of the filtration used in regions with a cold climate ${ }^{1}$. Features of this altered biodiesel, which is offered to consumers, mostly surpass the characteristics of mineral diesel. Since 2013 "LUKOIL Serbia" has been offering Biodiesel BD-100. In 2007, only one gas station in Belgrade had in its offer biodiesel, while according to the data from May 2013, Serbia has 50 service stations selling biodiesel.

The biogas power plant is designed in conformity with the existent energy policy that acknowledges the existence of producers of energy from renewable sources as producers with favoured status and guarantees the purchase of energy at subsidized prices. The investor company re-examined its own energy policy and brought it into agreement with the priorities of sustainable energy policy of the Republic of Serbia. The support system for producers of electric power from renewable resources in the Republic of Serbia has been maintained by the following legislative acts of the Energy Law:

- Decree on requirements for obtaining the status of privileged power producers and criteria for evaluating compliance with these requirements (3rd September 2009)

- Decree on measures of incentives for the production of electricity using renewable energy resources and combined production of electrical and thermal energy (Official Gazette of RS of 01/12/2009 No. 99/2009 year).

According to the above-mentioned acts, biogas (gas created from biomass in anaerobic processes) is defined as a renewable energy resource $[7,8]$.

Within the farm "Sava Kovacevic" in Vrbas, the construction of the plant for the production of biogas, which later converts into heat and electricity, worth of 5.5 million EU (figure 1), has been finished.

The performance of the project CDM (Clean Development Mechanism) in landfills in the cities of Užice, Čačak and Požega involves preparing three landfills for environmental closure. These municipalities, along with six other municipalities of the Zlatibor region, agreed to build a new general

\footnotetext{
${ }^{1}$ http://www.biofuelsystems.com
}

sanitary landfill. Thus, the existing landfill will cease operations in the next three years. An additional benefit of this project is to facilitate the collection and combustion of biogas from landfills. Biogas is a complex mixture of gases produced from organic waste due to microbial activity. The realization of the project requires an investment in the system of gas collection and purchase of equipment for the combustion of methane. Within this project, there will be a reduced risk of pollution of air, groundwater and soil for residents of areas close to existing landfills in the municipalities of Užice, Čačak and Požega, as well as on the territory of Zlatibor [12].
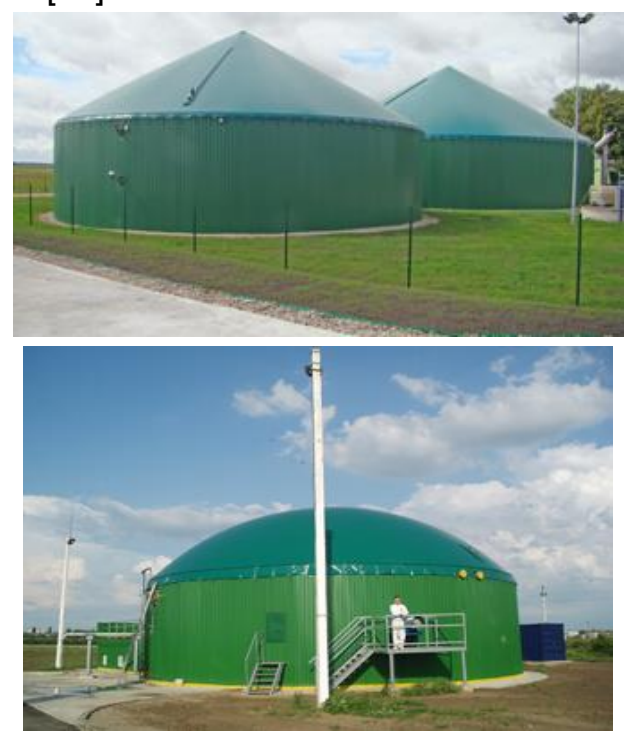

Figure 1 - General view of the production lines for the extraction of biogas

\section{WIND ENERGY RESOURCES \\ IN SERBIA AND RUSSIA}

Wind energy is an environmentally acceptable renewable energy source. Serbia has not built wind generator farms yet, but there are plans for their construction on the Vlasina, in Bela Crkva and on some other locations. One of the main objectives of the project "Strengthening of the Center for renewable energy sources in the Agency for Energy Efficiency" is to show that Serbia has the wind energy resources and to identify areas that have prospects for the production of electricity using wind. In Šajkaš (municipality of Titel), Veliko Gradiste and Negotin posts of $50 \mathrm{~m}$ high have been erected for the measurement of wind potential.

For the economic production of electrical power by modern wind generators, an annual average wind speed of five $\mathrm{m} / \mathrm{s}$ and more is required. This has been defined on the basis of the average wind speed at a height of $50 \mathrm{~m}$ above the ground for 10 minutes. By this criterion, Serbia has significant wind potential. The area with suitable wind amounts to $471.25 \mathrm{~km}^{2}$. The best wind is registered on Midžor $(7.66 \mathrm{~m} / \mathrm{s})$, Suva Planina $(6.46 \mathrm{~m} / \mathrm{s})$, 
Vršački Breg $(6.27 \mathrm{~m} / \mathrm{s})$, Tupižnica $(6.25 \mathrm{~m} / \mathrm{s})$ and Krepoljin $(6.18 \mathrm{~m} / \mathrm{s})$. In addition, there is a significant number of sites, with a total area of 244 $\mathrm{km}^{2}$, in which over $50 \%$ of the time in the year the wind blows with an average speed of over $6 \mathrm{~m} / \mathrm{s}$.

It is possible to construct wind generators of $1,316 \mathrm{MW}$ capacity if the medium wind speed is greater than five $\mathrm{m} / \mathrm{s}$. These capacities, assuming a low coefficient of capacity of 0.2 (in the world range from 0.25 to 0.4 ) would be able to produce about 2.3 TWh per year.

Under the German model, local communities will be encouraged to purchase wind turbines to generate electricity. Standard contracts will be made for the purchase of electricity from renewable energy sources.

By applicable international criteria, the wind energy resource of Serbia, whose activation would significantly increase the installed capacity, would contribute to the diversity of energy sources and reduce dependence on imports of energy.

For climate protection and the promotion of risk management system in the Spatial Plan of Serbia 2010-20, the priority strategic activities for the mitigation of climate change have been established. The Ministry of Infrastructure and Energy has prepared a Strategy for Implementation of Clean Development Mechanism (CDM) in the power sector of Serbia.

The National Strategy for the inclusion of Serbia into CDM, for the sectors of waste management, agriculture and forestry, was adopted in February of 2010 ("Official Gazette of RS", No. 30/10). The Strategy provides information on overall and priority resources for the implementation of CDM projects in the Republic of Serbia (National Environmental Protection Programme, 2010). In November 2010, the first report of the Republic of Serbia to the United Nations Framework Convention on Climate Change was adopted.

In February 2012, the project "Wind Farm Cibuk 1" (Municipality of Kovin, $171 \mathrm{MW}$ ) was recorded as the first CDM project. The design documents (PDD) for the projects, "Wind Farm Plandiste 1", "Wind Farm II Oro", "Wind Farm Cibuk 1", and "Reduce methane leaks in the distribution network of Srbijagas", were submitted to Designated National Authority of the Republic of Serbia (DNA), to implement the Clean Development Mechanism.

Official data indicate that the price of electric power produced by wind generators, for specific locations, is competitive with conventional sources. This trend will continue in the near future. The President of the U.S. company Continental Wind Partners, who plans to invest in the next four years in the development of wind farms Chibouk at Kovin, Mark Krendal said in Novi Sad that Vojvodina had good locations and high potential for wind energy. The first wind farm Chibouk at Kovin, Vojvodina, will be completed by 2014 .

Russia has a long tradition of small-scale wind energy use but has never sufficiently developed large-scale commercial wind energy production. Most of its present wind production is located in agricultural and rural areas with rather low population densities where adequate connection to the main power grid is difficult. Russia is estimated to have a very large for wind energy. Most of this obvious potential is discovered in the southern steppes and the seacoasts of Russia, although, in many of these areas, the population density is less than one person per square $\mathrm{km}$. Current Russian wind power projects have a combined capacity of over 1,700 MW. The wind power potential of Murmansk Oblast is one of the largest among Russian regions.

The Russian Wind Energy Association predicts that if Russia achieves its goal of having $4.5 \%$ of its energy come from renewable sources by 2020 , the country will have a total wind capacity of $7 \mathrm{GW}$. Plans for the construction of a wind power plant in Yeisk, on the Sea of Azov, were announced. By 2015 , the company hopes to install $1,250 \mathrm{MW}$ of capacity in Russia [7].

\section{UTILIZATION OF GEOTHERMAL ENERGY IN SERBIA AND RUSSIA}

The existence of large hydro geothermal convective system with the reservoir of the thermal low-mineralized water (temperature between 75 and $120^{\circ} \mathrm{C}$ ) is important for heating. Geothermal energy could be efficiently utilized for various purposes in the Republic of Serbia [4, 11,14] (table 1).

Horticultural hotbed gardens and greenhouses are usually growing near thermal springs. Thermal water is desirable for hotbed's heating. This water is useful for irrigation after cooling if its quality is suitable.

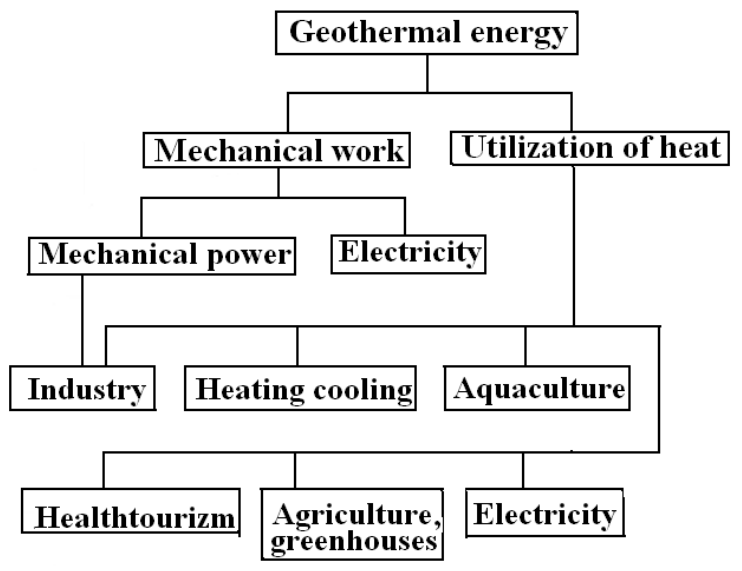

Figure 2 - Utilization of Geothermal Resources 
The German companies are in search of Serbian partners to engage in projects of the use of thermal energy sources. Serbia is rich in geother-

mal energy and has high natural and market potential for large investments in the area (figure 2).

Table 1 - Use of Thermal and Mineral Waters in Serbia

\begin{tabular}{|c|c|c|c|c|c|}
\hline Location & Type of use & Capacity kg/s & in & out & Used energy $\mathrm{T} J /$ year \\
\hline Kanjiža 1 & $D / B$ & 5.0 & 41 & 26 & 9.89 \\
\hline Kanjiža 2 & $\mathrm{D} / \mathrm{B}$ & 14.0 & 65 & 26 & 72.02 \\
\hline Kula 1 & $B$ & 9.5 & 50 & 25 & 46.16 \\
\hline Kula 2 & $\mathrm{I}$ & 8.3 & 53 & 25 & 30.65 \\
\hline Kula 4 & 1 & 8.5 & 51 & 26 & 28.03 \\
\hline B. Petrovac 1 & G & 16.7 & 46 & 25 & 46.26 \\
\hline B. Petrovac 2 & A & 7.8 & 45 & 24 & 21.60 \\
\hline Prigrevica & $\mathrm{D} / \mathrm{B}$ & 21.0 & 54 & 25 & 80.33 \\
\hline Srbobran & $\mathrm{G}$ & 11.7 & 63 & 24 & 60.18 \\
\hline Kikinda 1 & $\mathrm{D}$ & 6.2 & 50 & 27 & 18.81 \\
\hline Kikinda 2 & $\mathrm{~F}$ & 15.2 & 51 & 26 & 50.12 \\
\hline Mokrin & $\mathrm{F}$ & 10.5 & 51 & 26 & 34.62 \\
\hline Vrbas & B & 4.3 & 51 & 23 & 13.26 \\
\hline Temerin & B & 20.0 & 41 & 25 & 39.57 \\
\hline B. P. Selo & $\mathrm{F}$ & 10.0 & 43 & 26 & 34.29 \\
\hline Bečej & $\mathrm{D}$ & 19.4 & 65 & 24 & 104.91 \\
\hline Vranjska spa & $\mathrm{I} / \mathrm{F} / \mathrm{D} / \mathrm{B} / \mathrm{G}$ & 77.0 & 96 & 50 & 467.20 \\
\hline Sijarinska spa & $\mathrm{D} / \mathrm{B}$ & 7.4 & 76 & 25 & 49.78 \\
\hline Jošanička spa & $\mathrm{D} / \mathrm{B}$ & 17.0 & 78 & 40 & 85.21 \\
\hline Lukovska spa & $D / B$ & 12.0 & 67 & 35 & 50.65 \\
\hline Kuršumlija & $D / B$ & 20.0 & 68 & 25 & 113.43 \\
\hline Mladenovac & $B$ & 19.0 & 53 & 25 & 70.17 \\
\hline S. Palanka & $\mathrm{B}$ & 13.0 & 56 & 25 & 53.16 \\
\hline N. Pazar & B & 10.0 & 52 & 28 & 31.65 \\
\hline Mataruge & $\mathrm{B}$ & 47.0 & 43 & 24 & 117.79 \\
\hline Ribarska sp & $\mathrm{D} / \mathrm{B}$ & 37.0 & 44 & 25 & 92.73 \\
\hline Pećka spa & $B$ & 4.0 & 36 & 25 & 5.80 \\
\hline Ilidža (Peć) & $B$ & 17.5 & 48 & 26 & 50.78 \\
\hline Bujanovačka spa & $D / B$ & 7.0 & 43 & 24 & 17.54 \\
\hline Gamzigradska spa & $\mathrm{D} / \mathrm{B}$ & 10.0 & 42 & 24 & 23.74 \\
\hline Ovčarska spa & $\mathrm{D} / \mathrm{B}$ & 50.0 & 38 & 27 & 72.54 \\
\hline Vrnjačka spa & $\mathrm{B}$ & 5.0 & 36 & 25 & 7.25 \\
\hline Niška spa & $D / B$ & 60.0 & 37 & 25 & 94.97 \\
\hline Pribojska spa & $B$ & 70.0 & 36 & 30 & 55.40 \\
\hline Klokot & $B$ & 15.0 & 34 & 25 & 17.80 \\
\hline Koviljača & $B$ & 130.0 & 30 & 24 & 102.88 \\
\hline Brestovačka spa & B & 3.0 & 40 & 30 & 3.96 \\
\hline Rajčinovića spa & $B$ & 8.0 & 36 & 28 & 8.44 \\
\hline Bukovička spa & $B$ & 15.0 & 34 & 28 & 11.87 \\
\hline Prolom spa & $B$ & 15.0 & 31 & 24 & 13.84 \\
\hline G. Trepča & $B$ & 20.0 & 30 & 24 & 15.82 \\
\hline Debrc 1 & $\mathrm{D}$ & 15.0 & 53 & 48 & 9.89 \\
\hline Total: & & & & & 2335 \\
\hline
\end{tabular}

Type of use: I - Industry, A - Drying of agricultural products, F - Agriculture, D - Heating, B - Balneology, G - Hotbeds, Source: Milivojević \& Martinović [20] 
Selters spa, located on the hills of the Kosmaj mountain, is one of the spas that use geothermal energy. Surrounded by the forest terrain, this spa is famous for clean air and salubrious climate. Instead of fuel oil, the thermal water is used for heating of rooms. In this way, apart from the annual savings of 250 tons of fuel oil, an important step in the preservation of the natural environment is achieved at temperatures of above $50^{\circ} \mathrm{C}$, which is sufficient to heat approximately $30.000 \mathrm{~m}^{2}$.

During the flow of geothermal water through the installation, there may arise the changed corrosion behavior of metal materials. This occurrence causes constant amounts of the corrosion, thus bringing the new active substances such as oxygen, sulfur - hydrogen and carbon dioxide into contact with the surface of metal pipes, and other installations. Stainless steels, which have increased contents of titanium, chromium, and molybdenum, as compared with the steel of the type AISI 316 and Z04, indicate greater resistance to corrosion in geothermal water. More alloyed steels, socalled "superalloys," are much more resistant to corrosion. Alloys of titanium possess very good corrosion resistance even with the presence of dissolved oxygen. Most are used for making titanium plate heat exchanger at low temperature geothermal water.

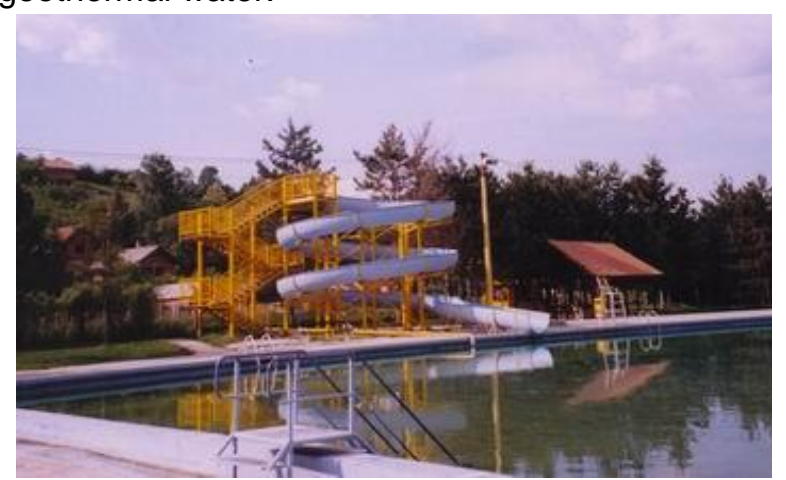

Figure 3 - Thermal water pool (Spa Vrujci)

Geothermal energy represents a very significant form of renewable energy in Russia. It is the second most used form of renewable energy in this country. Less than $1 \%$ of the total energy production goes to this form of energy. In 1966, the first geothermal power plant in Russia was built at Pauzhetka, Kamchatka, with an installed capacity of $5 \mathrm{MW}$. The total geothermal installed capacity in 2005 was 79 MW, with 50 MW coming from a plant at Verkhne-Mutnovsky. Most geothermal resources are currently being used for heating settlements located in the North Caucasus and Kamchatka. Half of the geothermal production is used to heat numerous homes and industrial buildings, and one third is used to heat greenhouses. Russia is also investigating foreign investment possibilities for developing geothermal energy in the Kuril Islands [21].

\section{SOLAR ENERGY}

In 2012, the solar company Danone from Belgrade, started work on the installation of solar collectors in elementary school "Dr. Jovan Cvijic" in Smederevo. The installation of the first solar energy collector is the realization of a larger project of the city of Smederevo that includes greater use of renewable energy sources in public facilities, and preserving the environment.

The Hotel "Olimp" at Zlatibor has been using solar energy for heating of water for the last three years. Solar heaters can heat such a quantity of water that it is enough to heat the hotel swimming pool. According to the statements made by employees from the hotel's technical department, approximately five tons of warm water are available at any moment. The capacity can be increased to over seven and half tons during warm and sunny days. The Hotel "Elite" is also using renewable resources of energy. From the design stage of the hotel building, care has been taken about the preservation of energy. While solar energy is being used to heat the water, energy of warm underground waters is being used for central heating.

Despite the high capabilities in the application of solar energy in Russia, as well as in Serbia, solar energy sources are still little used.

The first Russian solar plant was put into operation in Belgorod Oblast in 2010. Russia has a total potential of 2,213 TWh/yr for solar energy, with an economically feasible amount of $101 \mathrm{TWh}$. The southern parts of Russia, according to experts, especially the North Caucasus, have the highest potential for solar energy.

A newly-built solar plant on the Black Sea began its operations in 2012. This plant has a capacity of $12.3 \mathrm{MW}$, and Rusnano and Renova built it. Solar Wind LLC and Rusnano are constructing facilities that will produce double-sided solar panels, which will be able to collect solar energy from both sides. Nitol Solar is the largest Russian company in the area of scientific development and manufacture of products used to generate solar energy [3]. Russia and India are currently discussing the possibility of a joint venture agreement to produce silicon wafers for the creation of photovoltaic cells [19].

One of the world's largest private oil company "LUKOIL" has also begun to invest in solar energy projects within synergy projects. In 2009, the company put into operation its first solar gas station in Serbia, followed by the Krasnaya Polyana not far from the city of Sochi. This system is particularly important in mountainous areas, as it allows 
uninterrupted power supply even during emergency power outages. Maximum capacity of the solar LUKOIL gas station in Krasnaya Polyana is $9.6 \mathrm{KW}$.

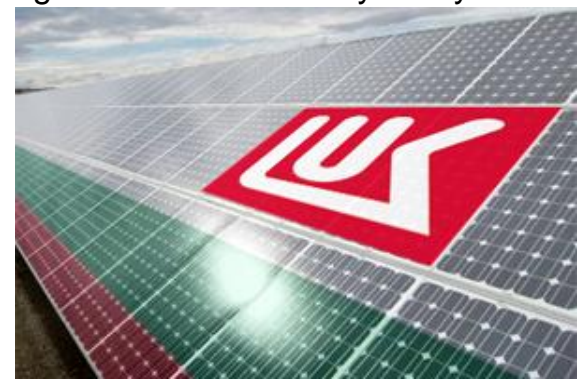

However, the company did not stop at this. In December 2011, "LUKOIL" put into operation its first large-scale solar-energy power plant within the "Lukoil Energy and Gas of Bulgaria." The project was implemented in the city - resort of Burgas, in which the company has been working for a long time, and where there is the largest refinery in the Balkans "LUKOIL Neftochim BURGAS." The capacity of the power plant is 1:25 MW while annual energy production is expected to reach 1,500 MWh. "LUKOIL" has invested about $\$ 4$ million in this project.

In addition, "LUKOIL" is working with the Government of Uzbekistan and the bank, "Asian Development Bank" on the project of the construction of the solar power capacity of $100 \mathrm{MW}$.

\section{WATER ENERGY}

Hydropower is the widely used form of renewable energy in Russia, and there is enormous potential in Russia for greater use of hydropower $[1,2,15,17]$. Russia has a total of 102 hydropower plants with installed capacities of over $100 \mathrm{MW}$, which ranks this country fifth in the world for hydropower production. It also ranks second on the planet for hydro potential. However, only $20 \%$ of this potential is developed [10]. Russia possesses $9 \%$ of the world's hydro resources, mostly in Siberia and in the country's far eastern territories. At the end of 2005, the generating capacity from hydroelectric sources in Russia was $45,700 \mathrm{MW}$, while an additional 5,648 MW was under construction. According to the World Energy Council, Russia has high potential for using its hydro resources, with the potential of about 2,295 TWh/yr, and with 852 TWh being economically feasible. RusHydro is the largest hydroelectric business in Russia. This company is also the second largest hydroelectric producer in the world.

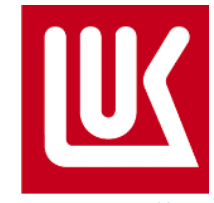

лукОйл
"LUKOIL" is in second place among the largest producers of hydropower in Russia with a total capacity of $0.3 \mathrm{GW}$. The production of electricity from hydro power plants has already become sufficiently developed sector in the field of renewable energy. Their percentage growth is not as high as it was the case with the new types of energy production from renewable sources, but it is a steady source of "green" energy when reliability and high efficiency power plants are taken into account.

Inventories of renewable energy sources in Serbia are high. For example, the number of sites on rivers suitable for the construction of small hydropower plants is bigger than 800 . However, permit for the construction of small hydropower plants received about 60 projects. There are often interruptions on project work due to difficulties in obtaining permits based on the assessment of environmental impacts. In addition, a major problem is the financing of the construction and purchase of equipment. Not all proposed projects are covered with financial resources $[7,8]$.

In cooperation with 17 municipalities in Serbia, Ministry of Energy of the Republic of Serbia has prepared a competition for the award of 317 locations for the construction of mini-hydropower plants in Serbia. The Serbian government adopted a decree on the introduction of preferential tariffs for purchase of electricity produced from renewable sources, which entered into force on 4 February 2013.

Table 2 - Projects for small hydropower plants (until 26 February 2013)

\begin{tabular}{|c|l|l|}
\hline & Project Initiator & \multicolumn{1}{|c|}{ Name of Project } \\
\hline 1 & $\begin{array}{l}\text { Igis Imako } \\
\text { d.o.o. }\end{array}$ & $\begin{array}{l}\text { Construction of small hydropower } \\
\text { plant "Metovnica" }\end{array}$ \\
\hline 2 & $\begin{array}{l}\text { Igis Imako } \\
\text { d.o.o. }\end{array}$ & $\begin{array}{l}\text { Construction of small hydropower } \\
\text { plant "Ribare" }\end{array}$ \\
\hline 3 & $\begin{array}{l}\text { Igis Imako } \\
\text { d.o.o. }\end{array}$ & $\begin{array}{l}\text { Construction of small hydropower } \\
\text { plant "Zlot" }\end{array}$ \\
\hline 4 & $\begin{array}{l}\text { Igis Imako } \\
\text { d.o.o. }\end{array}$ & $\begin{array}{l}\text { Construction of small hydropower } \\
\text { plant "Prevale" }\end{array}$ \\
\hline 5 & $\begin{array}{l}\text { Igis Imako } \\
\text { d.o.o. }\end{array}$ & $\begin{array}{l}\text { Construction of small hydropower } \\
\text { plant "Jelašnica" }\end{array}$ \\
\hline 13 & $\begin{array}{l}\text { Igis Imako } \\
\text { d.o.o. }\end{array}$ & $\begin{array}{l}\text { Construction of small hydropower } \\
\text { plant "Drvnik" }\end{array}$ \\
\hline 14 & $\begin{array}{l}\text { Eco Energo } \\
\text { Group d.o.o. } \\
\text { Belgrade }\end{array}$ & $\begin{array}{l}\text { Construction of small hydropower } \\
\text { plant "Jabukovik" on the town } \\
\text { river Crna Trava, Serbia }\end{array}$ \\
\hline 1 & $\begin{array}{l}\text { Municipality of } \\
\text { Ljubovija }\end{array}$ & $\begin{array}{l}\text { Construction of small hydropower } \\
\text { plant "Bijela“ }\end{array}$ \\
\hline 2 & $\begin{array}{l}\text { Municipality of } \\
\text { Ljubovija }\end{array}$ & $\begin{array}{l}\text { Construction of small hydropower } \\
\text { plant "Jelice" }\end{array}$ \\
\hline 3 & $\begin{array}{l}\text { Municipality of } \\
\text { Ljubovija }\end{array}$ & $\begin{array}{l}\text { Construction of small hydropower } \\
\text { plant "Ravna gora“ }\end{array}$ \\
\hline 4 & $\begin{array}{l}\text { Municipality of } \\
\text { Ljubovija }\end{array}$ & $\begin{array}{l}\text { Construction of small hydropower } \\
\text { plant "Osojača I“ }\end{array}$ \\
\hline
\end{tabular}




\section{TIDAL ENERGY}

Russia has substantial tidal energy resources at its disposal. However, these resources are not currently developed. The Kola Bay and Sea of Okhotsk alone could produce $100 \mathrm{GW}$ with tidal power stations. The national energy potential from tidal energy can vie with current total power production in the country. The currently active Kislaya Guba Tidal Power Station is the largest tidal power facility in Russia and has the fourth largest capacity (1.7 MW) among the world's tidal power plants [9].

\section{CONCLUSION}

The ecological standards of developed countries, according to Kyoto Protocol are growing because the production of biodiesel receives a greater stimulus. The reasons for the sudden increase in production of biodiesel fuel are the need of the struggle with air pollution and climate changes, growth and fluctuations of oil prices, as well as the need for ecologically clean fuel.

The need of fast solution of global environmental and economic problems leads to expansion in the study and the use of renewable energy sources (biomass, geothermal energy, wind energy, solar energy). The largest contributory amounts of all renewable energy sources in the nearest future is expected from biomass.

Serbia is rich in renewable energy resources. Biomass, together with its products such as biofuels and biogas, are fuels from renewable resources like plants and animals sources.

A key requirement for the general production of biodiesel and biogas in Serbia will be the introduction of economic measures that will allow that the prices of biodiesel and biogas be competitive compared to the price of mineral fuels. The most important measure is the total or partial exemption from excise duty on biodiesel. A particular problem is the unregulated market of oilseeds, which is characterized by fluctuations in prices due to more limited areas under oilseeds.

In most cases, the production of electricity from renewable resources is more expensive than energy production from fossil fuels. Thus, the socalled support systems have been introduced, i.e. financial and non-financial measures of incentives to invest in facilities that use renewable energy.

Intensive exploitation of the renewable resources must become one of the important goals overall economic development in Serbia.

Energy Policy of the Republic of Serbia and Russia is entirely based on the principles of sustainable development and the Kyoto Protocol.

\section{Acknowledgements}

This study is part of the Interdisciplinary research projects III 47009 and III 43009 which are supported by the Ministry of Education, Science and Technological Development of Serbia in the period 2011-2014.

\section{REFERENCES}

[1] Amstell D. "Russian Energy efficiency". Power \& Energy. (10 December 2009).

[2] Basic indicators of organisations by kind of economic activities - production and supply of electricity, gas and water. Federal State Statistics Service. 2010.

[3] Bush J. "Nitol, Russia's Emerging Solar Power Star". Spiegel Online International. (14 July 2009).

[4] Database of mineral and thermomineral waters of Serbia. Geoinstitute, Belgrade 2000.

[5] Ermakov V. V, Jovanovic L. Sustainable development and evolution of energy and living matter in the biosphere// Ecologica, 2011. Vol. 18. No. 62. P. 85-94. ISSN 0354-3285

[6] "First Biofuel Plant to be built in Russia". Russian Geographical Society. 19 October 2010.

[7] Garcia H. "Siemens makes a bid for Russia's wind power through joint venture". Ecoseed. (16 July 2011).

[8] Golušin M., Dodić S., Vučurović D., Ostojić A., Jovanović L., (2011), Exploitation of biogas power plant CDM Project, Vizelj, Serbia, Journal of Renewable and Sustainable Energy 3, No 5, 052701, pp. 1-11, doi: $10.1063 / 1.3631820$

[9] Golušin M., Dodić S., Vučurović D., Jovanovic L., Munitlak Ivanović O., (2012), Sustainable energy management in industry of Republic of Serbia. Biogas power plants advantages, Industrija 40, No 4, 107-124.

[10] Gorlov A. M. "Tidal Energy". Northeastern University, 2001.

[11] "Hydropower in Russia". RusHydro. 2008-2009.

[12] Jovanović L. The possibilities of exploitation of Serbian thermomineral waters. In: D. P. Antić and J. Lj. Vujić (eds.), Environmental Recovery of Yugoslavia (ENRY 2001), Belgrade, 2002, 747-751.

[13] Jovanovic L., Cvijic L., Tomic A., Radosavljevic M.: The CDM project activity in the Republic of Serbia, 8th Conference on Sustainable Development of Energy, Water and Environment Systems (SDEWES 2013), Dubrovnik (Croatia) 2013, Digital Proceedings, Paper 0251, pp. 1-7, ISSN 1847-7178.

[14] Jovanović L., Petrović D., Primena energetski efikasnih tehnologija u kompaniji „LUKOIL Srbija“, Međunarodna konferencija "Sustainable Economy and Environment", Belgrade, Proceedings (2014)

[15] Jovanović L., Stojadinović D. Managing of water resources in urban areas of Serbia. 4th European congress on regional geoscientific cartography and information systems, Bologna 2003, Proceedings, v. I, p. 216.

[16] Kajaste R. "NEFCO Renewable Energy Projects in Russia". NEFCO. (23 October 2008).

[17] Karjalainen T., Gerasimov Yuri. "Energy Wood Potential in Northwest Russia". Finnish Forest Research Institute. (September 2008). 
[18] Kostomarova A., Blake J. "Russian renewable energy prepares for a bigger slice of the power pie". Business RT. (25 August 2009).

[19] Kramer A. "Decaying Soviet Infrastructure Shows Its Era". The New York Times. (20 August 2009).

[20] Milivojević M., Martinović M. (1996), Geothermal resources of Serbia and Montenegro - potential, performed exploration, use and possibilities for development. Ecologica No 3, 21-38
[21] Morarjee R. "Red to green: Russia begins energy saving". Business New Europe. (18 November 2010).

[22] "Moscow ready to offer breaks to foreign investors on Kurils". RIA Novosti. 11 February 2011.

[23] Veljković N., Praćenje održivog razvoja u Srbiji, Agencija za zaštitu životne sredine, 2010.

\section{IZVOD}

\section{OBNOVLJIVI ENERGETSKI RESURSI U SRBIJI I RUSIJI}

Energetska politika Republike Srbije i Ruske Federacije je u potpunosti zasnovana na principima održivog razvoja i Kjoto protokola. Ovaj rad analizira specifičnosti energetske politike u Srbiji i Rusiji $i$ daje primere određenih vrsta energija. Srbija i Rusija bogate su obnovljivim energetskim resursima. Istraživanja mineralnih i termomineralnih voda sprovedena u Srbiji pokazuju visok kvalitet mineralnih voda koje su mogu primeniti u medicinske svrhe. Mineralni i termomineralni banjski izvori u Srbiji predstavljaju prirodne resurse sa velikim mogućnostima u razvoju turizma, poljoprivrede i ekonomije. Posebna pažnja mora se usmeriti na multidiscciplinarna istraživanja u cilju prikupljanja relevantnih podataka potrebnih za upotrebu svake vrste termomineralnih voda. Intenzivna eksploatacija obnovljivih resursa mora postati jedan od važnih ciljeva privrednog razvoja Srbije.

Ključne reči: izvori obnovljive energije, biomasa, biogorivo, energija vetra, energija vode, geotermalna energija, Republika Srbija, Ruska Federacija.

Pregledni rad

Primljeno za publikovanje: 10. 01. 2014.

Prihvaćeno za publikovanje: 16. 04. 2014. 